\title{
The Plutarch of Maoriland: James Cowan and Pictures of Old New Zealand
}

\author{
ROGER BLACKLEY
}

\begin{abstract}
James Cowan's Pictures of Old New Zealand (1930) documents the Partridge Collection of paintings by Gottfried Lindauer in full-page, half-tone illustrations accompanied by historical biographies. Lavish by New Zealand's publishing standards of 1930, the book originated in an earlier, unillustrated guide to the collection overseen by a much younger Cowan in 1901. This essay discusses the genesis of many biographies in manuscripts solicited by Partridge from his friend James Mackay, a "fixer" between Māori and Pākehā worlds in the late nineteenth century who personally knew many of the subjects. It further argues that Cowan's Pictures of Old New Zealand deserves recognition as the first significant art monograph to be published in New Zealand.
\end{abstract}

In a fulsome review of James Cowan's Pictures of Old New Zealand: The Partridge Collection of Maori Paintings by Gottfried Lindauer, ${ }^{1}$ the Times Literary Supplement remarked that the author had contributed more than mere letterpress to the pictures: "He has provided brief biographical sketches of the principal characters, and his Plutarchian eye for the picturesque in speech and incident has made them real works of art." "2 By New Zealand publishing standards of 1930, the Whitcombe and Tombs production was substantial and decidedly lavish, featuring full-page glossy illustrations of Lindauer's paintings alongside biographies of varying length. The image on the cover depicts the famous life mask of Wi Te Manewha, cast by Lindauer and Walter Buller directly from the chief's face at Cambridge in 1883. Interestingly, Partridge's painted version of the mask "completes" Te Manewha's moko, whereas Lindauer's more accurate oil portrait shows that his upper forehead was smooth.

Over the past century the book has gradually slipped from view, never being reprinted and failing even to achieve a mention in David Colquhoun's 1996 entry on Cowan in the Dictionary of New Zealand Biography. ${ }^{3}$ It would seem that, apart from art historians writing about Lindauer, and descendants of the portrait subjects, hardly anyone knows about the book. This essay explores the circumstances in which James Cowan became the biographer of Partridge's gallery of Māori celebrities, and interrogates the twenty-first-century status of Pictures of Old New Zealand. Is the compilation merely an exercise in journalistic bricolage, or does Cowan's book make a significant contribution to New Zealand's historical literature?

The impressive 220-page volume of 1930 had its origins in a modest 68-page booklet called Maori Biographies: Sketches of Old New Zealand, produced in 1901 as a guide to the gallery of Māori portraits that the collector and businessman Henry Partridge had recently opened on Auckland's Queen Street. ${ }^{4}$ We do not know when or how Partridge met the young journalist from the Auckland Star, who had already garnered praise for his commentaries on Māori events, but it is likely to have been in connection with the enthusiastic Māori reception of Partridge's gallery. It must have been Cowan who reported on the visit by King Mahuta on 29 August 1901, made in the company of his uncle, Patara Te Tuhi, who was then acting as an informant to Cowan. ${ }^{5}$ Included in the account was a translation of the inscription that Mahuta made in the visitor's book, which Cowan used to represent the speech that had concluded the visit: 


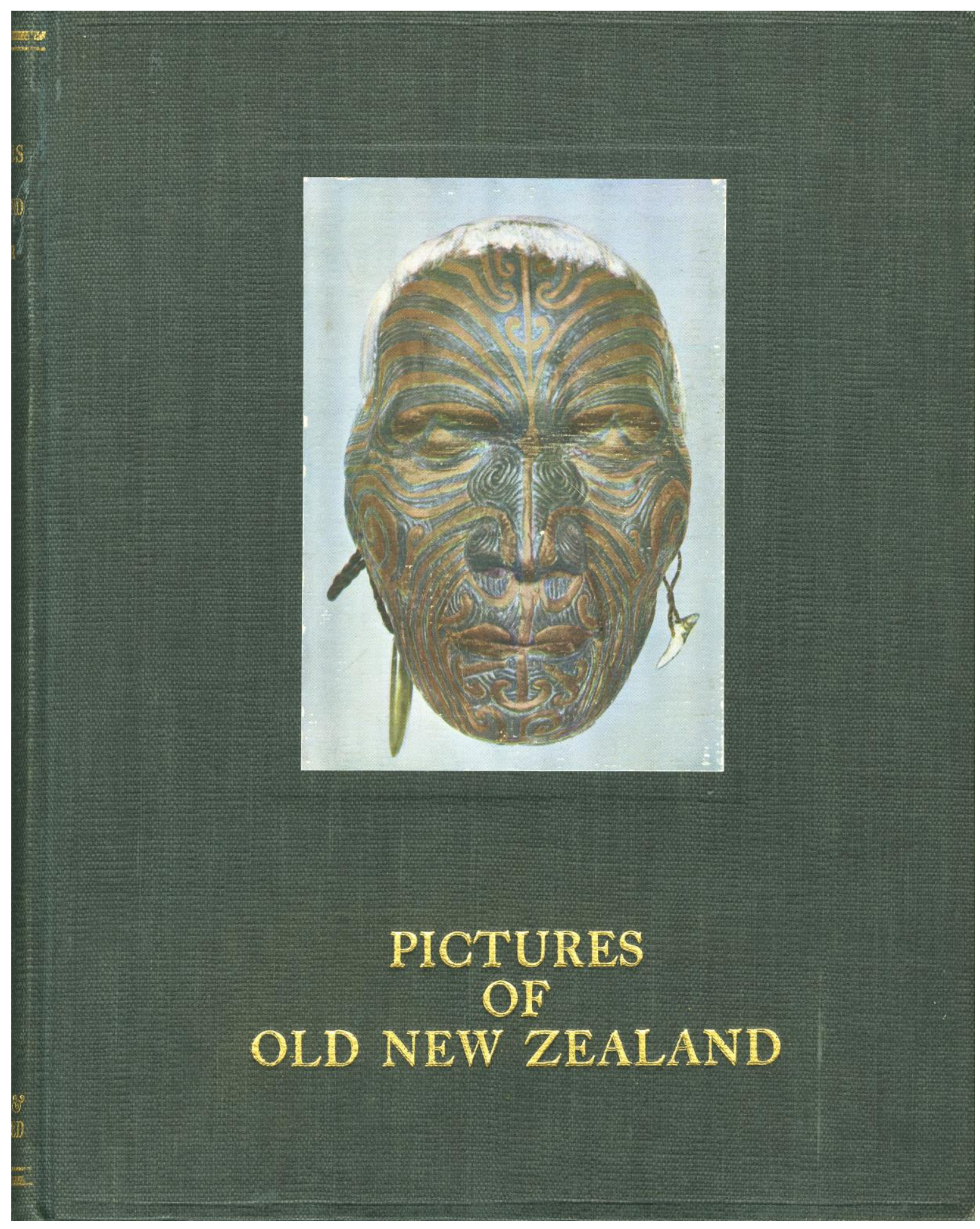

Figure 1. Pictures of Old New Zealand (1930) 


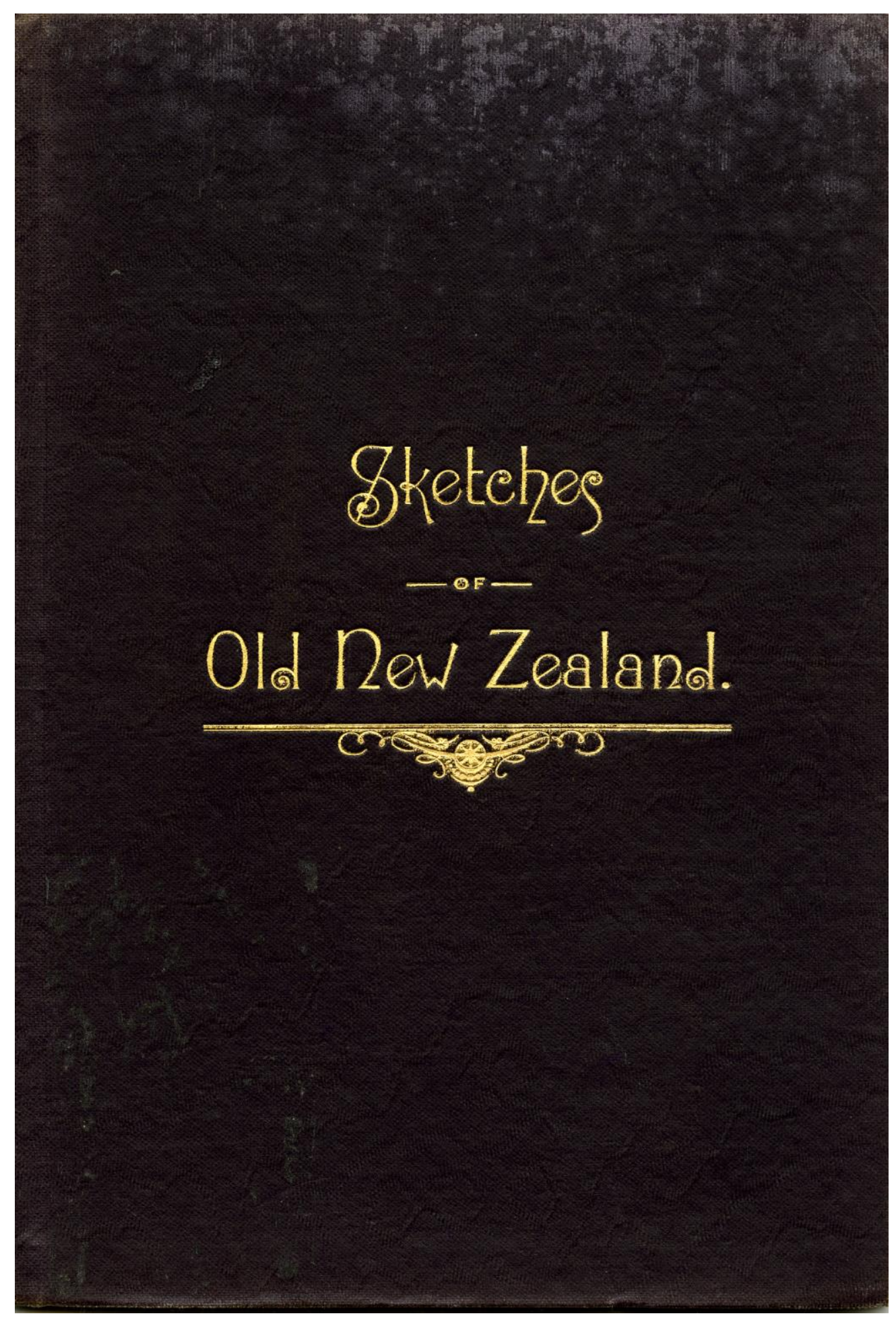

Figure 2. Maori Biographies: Sketches of Old New Zealand 
Mahuta, before leaving the gallery, made a characteristic speech. Looking round at the pictures of old warriors and tribal leaders, long since dead, he said: "I have looked upon these paintings of the Maori chiefs of Aotearoa and Te Wai-pounamu (the North and South Islands). My heart fills with grief at the sight of these likenesses of my ancestors, my fathers and mothers. Salutations to all of you here assembled (addressing the pictures)! Greetings also to the man who painted the pictures, the owner of them and the person who has them in charge. God save you all!"6

Cowan's close association with the Māori world, and the vivid writing style with which he communicated this world to a Pākehā readership, inspired Partridge to commission the young writer to profile the forty portraits that then comprised the collection. ${ }^{7}$

At the time of the Partridge Collection's accession by the Auckland Art Gallery in 1915, readers of the New Zealand Herald were told that "biographical information has been gathered by Mr. James Cowan and Mr. H. E. Partridge. The chiefs themselves, sons, daughters, and relatives were interviewed, and 15 years' travelling was spent in search of this information." 8 The title page of Maori Biographies states that they were "compiled by James Cowan." However, Cowan had inherited a sequence of texts on Hauraki, Waikato and Tauranga subjects solicited by Partridge from one of his main collaborators, James Mackay. ${ }^{9}$ A leading figure in the opening of the Thames Goldfield in the late 1860s and early 1870s, Mackay experienced the highs and lows of exploding wealth and subsequent bankruptcy, all the while accruing crucial expertise in the Māori world. A comparison between Mackay's material, held in the Partridge papers at the Auckland Art Gallery, and their published realisations, reveals the ways in which Cowan incorporated, augmented and altered a key source in creating the compilation. ${ }^{10}$

When Mackay's manuscript texts are compared with the published equivalents, we see that Cowan almost always inserted additional material. For example, in the text on the portrait of Mere Kuru Te Kati, the indomitable "ariki tapairu" of Ngāti Tamaterā, Cowan opened with an evaluative comment on the portrait: "One of Lindauer's later works, and ... one of his best, a perfect reproduction of the flesh colour of the Maori, the wrinkled face of the venerable kuia, the blue-tattooed lip and chin."11 himself:

Cowan also added a revealing conclusion that must have been related by Partridge

Many of these dignified old Maori chiefs and chieftainesses instinctively abhorred the idea of having their portraits painted or being sketched or photographed, and this dislike was shared by pretty well every member of their tribe. In the case of old Mere Kuru, the artist and Mr. Partridge were compelled to spend quite a considerable amount of time and money in their endeavours to persuade her immediate relatives to request Mere Kuru to give a few sittings. They probably would have failed but for the fact that they finally secured the assistance of Mr. James Mackay, whose great influence with the tribe at last overcame their objections and secured their consent and that of the old lady herself on the promise that a copy of the portrait would be sent them to hang in the tribal meeting house. ${ }^{12}$

Despite Mackay having originated almost everything except this final paragraph, Cowan's published version of the text merely allocated him the role of principal agent in the negotiations that resulted in the portrait. It is a subtle sleight of hand, perhaps, but one that successfully blurs the precise degree of Cowan's contribution. 


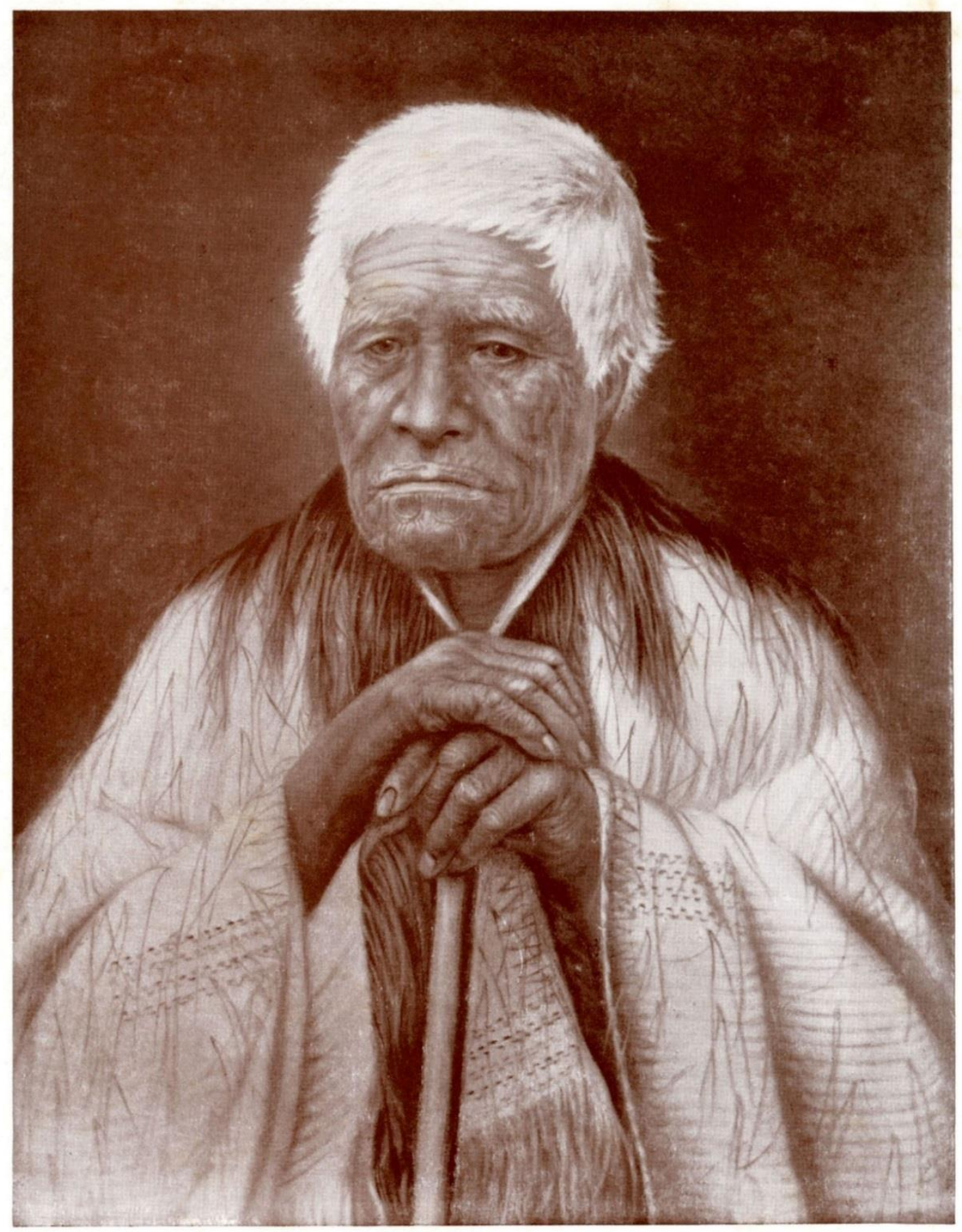

No. 21-Mere Kuru te Kati

[See Page 73 $-.4515:-\infty$

Figure 3. Portrait of Mere Kuru Te Kati, Pictures of Old New Zealand 


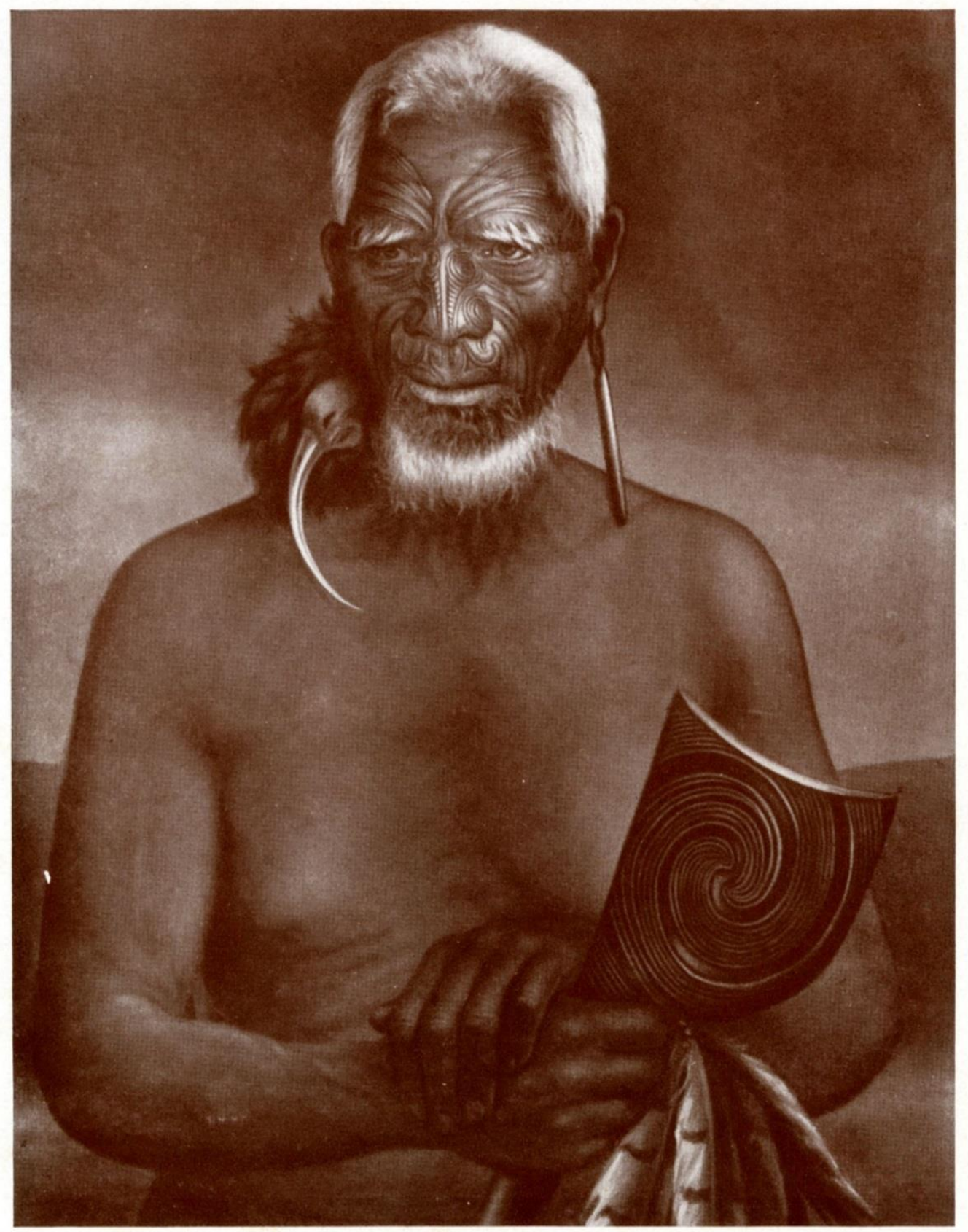

No. 20-Tukukino

[See Page 59 $-* 36+6$

Figure 4. Portrait of Tukukino, Pictures of Old New Zealand 
For the entry on Tukukino, Cowan reproduces Mackay's minimal text but again makes strategic modifications. Whereas Mackay referred to Mere Kuru as Tukukino's "colleague," Cowan substitutes "kinswoman." And once again, Cowan introduces Mackay as a character within the text: "Mr. James Mackay, Native Agent, who was chiefly instrumental in overcoming the scruples of the Maoris and in opening up the Ohinemuri, describes Tukukino as a "pretty good fellow but intensely obstinate." Cowan then added a fresh conclusion that leads us back to the portrait and its eye-catching decorative element: "The old chief was a cannibal, like Taraia, in his young days, and had taken part in many wars. In the picture he is shown wearing the dried skin of a huia bird in his ear, a typical ornament of a high-born Maori chief of former days." 13

In the case of Taraia, another kinsman of Mere Kuru, Cowan realised that he needed to include more than was offered by Mackay's brief, dismissive evaluation, which read: "Was an unscrupulous, treacherous, bloodthirsty savage. In 1842 he held the last cannibal feast of Maori bodies, the victims being some Tauranga Natives whom he murdered at Ongare near Katikati." Instead, Cowan chose to conjure a generous, three-page biography, which he opened in highly picturesque fashion:

This fierce old cannibal chief, Taraia Ngakuti Te Tumuhuia, will live in New Zealand history as a thorough-going representative of the barbaric past, a savage of the savages. He is shown in fighting costume, with his war-tomahawk in his hand. He died at his village at Ohinemuri ... in $1871 .^{14}$

Cowan draws on Māori oral history as well as Pākehā published history, including John Logan Campbell's Poenamu of 1881, in order to produce an account of Taraia's eventful career that begins with the warrior's 1824 expedition to the Hawke's Bay. Ngāti Toa sources inform an account of the 1831 campaign led by Te Rauparaha against Ngāi Tahu, in which Taraia and several Ngāti Tamaterā comrades collaborated. And the infamous Katikati episode of 1842 is carefully contextualised, with the evident assistance of close associates:

Taraia on being spoken to about his conduct, replied that it was a matter in which natives alone were concerned, and he did not see what business the Governor had to interfere in it. He also said he had heard that the Governor intended sending soldiers to capture him, that the Europeans informed him he would be hanged. "If this is true," said the savage warrior, "I will first take payment for myself, meaning that he would kill some Europeans as satisfaction for his own death. "What relation is the Governor to Whanake?" (the chief killed at Katikati), he exclaimed, "that he should love him so much? I have no objection to pay his people provided they pay me for all my relations whom they have killed. Have they not eaten my mother?"15

Then came Cowan's concluding comment: "And the Governor prudently left him alone."

The deployments of Mackay's texts raise an issue that is faced by all who use archival documents in their work. When are we happy to paraphrase, and when do we distance ourselves through quotation? Whether we like it or not, most of us would agree that we are often complicit in the subtle regurgitation of material, probably decorated with a footnote or two in order to indicate our sources. But how often, when confronted with something strange or controversial, do we reach for quotation marks in order to distance the text? This problem is clearly evidenced in the entries profiling the Ngāiterangi chiefs, Hamiora Tū and Tōmika Te Mutu. The entry on the former-an ally of the Crown-unproblematically reproduces Mackay's text, and is presented as if written by Cowan himself. Meanwhile, the adjacent text profiling Tōmika Te Mutu has Mackay's authorship firmly acknowledged: 


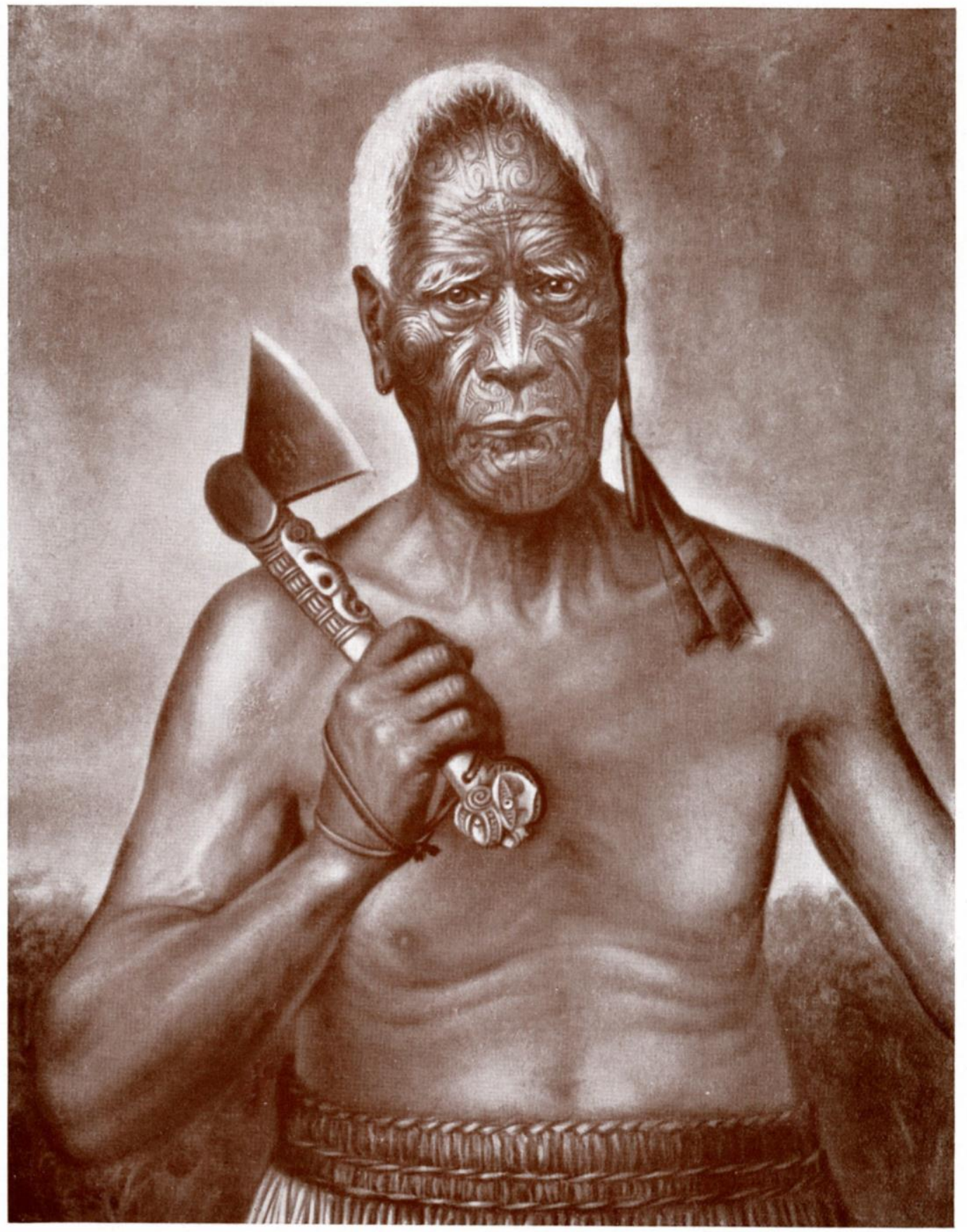

$$
\text { No. 19-Taraia }
$$

Figure 5. Portrait of Taraia, Pictures of Old New Zealand 
Mr. James Mackay (late Civil Commissioner) gave the following unflattering description of him:- "He was a truculent, treacherous savage, who in the wars between the Thames and Tauranga tribes kept himself out of the fighting and danger by playing fast and loose with both sides alternately. During the Europeans' fighting at Tauranga he pursued the same tactics as those for which he had previously distinguished himself in Maori warfare. He had a sullen morose appearance, which was increased by the darkness and close tattooing of his face." 16

I recall facing this very dilemma - the sifting of suitable from unsuitable - when, as a curator in search of appropriate information for a wall text, I would consult Pictures of Old New Zealand. ${ }^{17}$ Texts posted on an art gallery wall inevitably contribute to the vigorous afterlife of Cowan's book, one that reverberates through a range of publications on the Partridge Collection that now includes a website, Lindauer Online. ${ }^{18}$

Cowan drew on other writers, as well, whose contributions had been solicited by Partridge. One was Major John Wilson of Cambridge, a Waikato war veteran whose wife Te Aorere was custodian of Korotangi, the mysterious stone bird talisman of the Tainui waka. In the entry profiling Wahanui Reihana Te Huatare, Cowan introduced essential biographical data, including details of Wahanui's education at the Three Kings Wesleyan College in Auckland and his active service on the Waikato side during the war of the 1860s. The magic of the entry, however, is supplied by Wilson's evocation of Wahanui's supremacy in the realm of oratory:

To observe the action and gesture-not much of either-the gracefulness personified, of this ponderous Demosthenes action which the best of our English tragedians might emulate, but whose perfection in that respect he may never hope to reach, was worth a long day's journey to behold. His sonorous sentences and graceful accompanying gestures electrified even opponents, and drew forth the admiration of those who understood not one word of the language spoken, even as in Italian opera an English audience will sit spell-bound for hours. ${ }^{19}$

Throughout the biographies, Cowan explicitly cites a wide tranche of the New Zealand historical bookshelf, including Gorst's The Maori King, Percy Smith's History and Traditions of the Taranaki Coast, Davis's Life and Times of Patuone, Maning's Old New Zealand, Gudgeon's Reminiscences of the War in New Zealand, Taylor's Te Ika a Maui and New Zealand Past and Present, Porter's Ropata Wahawaha, and Rees's Life and Times of Sir George Grey. There are even a few lines from Domett's Ranolf and Amohia. ${ }^{20}$

Thus far I have stressed Cowan's role as an editor, or collator; how he places extant texts into fresh contexts. But there are many passages in which Cowan reveals episodes from his own life, such as when he recalls travelling as an Auckland Star journalist on James Carroll's 1895 expedition into Tūhoe territory. ${ }^{21}$ And it is made clear that the scintillating anecdotes in his life of Carroll came from the subject's own lips, when interviewed by Cowan near the end of his life. For me, the most compelling of these personally recounted lives is that supplied by Paratene Te Manu of Ngāti Wai, who met Cowan in 1895 on Hauturu, Little Barrier Island, when the journalist accompanied Crown officials delivering the chief's eviction notice: 


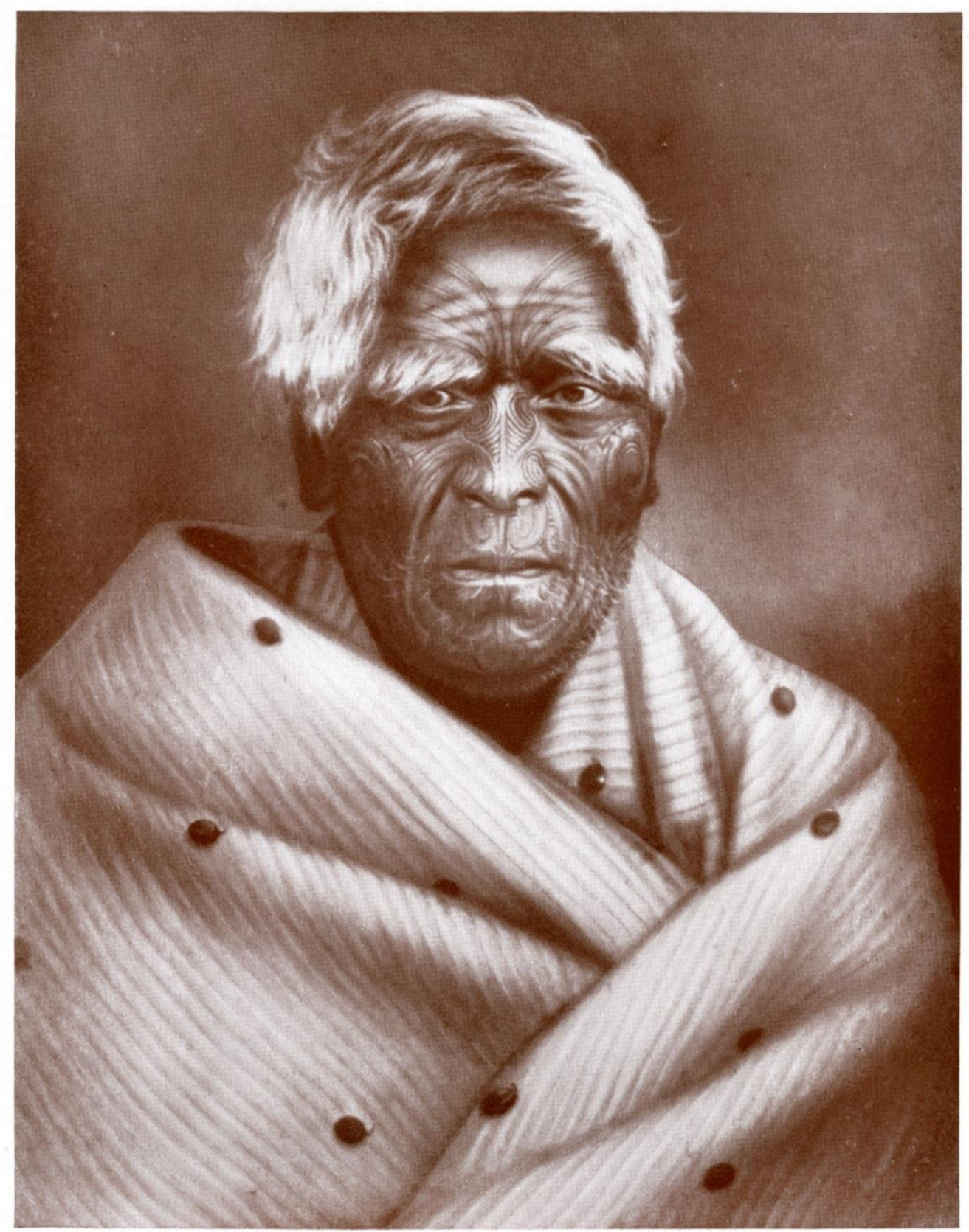

No. 25-Paratene te Manu

[See Page 78 $\rightarrow$ of $65+5$

Figure 6. Portrait of Paratene Te Manu, Pictures of Old New Zealand 
The ancient warrior, bent with age, would not touch his summons so it was laid on the ground at his feet. He picked up a manuka stick and danced feebly around the obnoxious paper, making digs at it as if he were spearing an enemy. ${ }^{22}$

Cowan asked Paratene for an account of his life, to which the elderly chief assented. But he explained that, since it was a long story, he would dictate it to one of his relatives on the island. "This relative, Mrs Kiri Paraone," explained Cowan, "faithfully wrote down in Maori the story as it fell from the old man's lips, and many weeks later I received the laboriously written notes." What Cowan now presented was "a literal and verbatim translation of Paratene's autobiography" - essentially a sequence of war expeditions, beginning with his whawhai tuatahi at Tāmaki as part of Hongi's devastating attack on Mauinaina, in which full use was made of the weaponry recently brought back from England and New South Wales. The final episode is a narrative of Paratene's trip to England in 1862, including the spectacle of the railway station with the trains that he termed "taipo," or demons, and the climax of their presentation to Queen Victoria. Cowan's entry on Paratene Te Manu in the 1901 Maori Biographies had been relatively brief, and entirely paraphrased; three decades later, he exhumed Mrs Paraone's manuscript in order to present a lengthy narrative in Paratene's authentic voice. Unfortunately, the original manuscript seems to be absent from Cowan's surviving papers.

On a number of counts, Pictures of Early New Zealand requires recognition as the first New Zealand art monograph - an honour usually accorded to E. H. McCormick for his 1956 introduction to Eric Lee-Johnson. ${ }^{23}$ Cowan's work, a far more substantial publication from a quarter-century earlier, is surely a deserving candidate. After all, the book performed through the twentieth century as the definitive catalogue of the 70 paintings produced by Gottfried Lindauer for Henry Partridge, and provided extensive information about the depicted individuals. A remarkable feature is the appendix of translated excerpts from the Lindauer Art Gallery's visitors' books, which marks Cowan's book as the first monograph on a New Zealand artist to take account of the bicultural reception of that artist's work. ${ }^{24}$ Even the opulent character of the book - the weighty heft of the paper, the full-page glossy illustrations - would argue for its status as an art monograph.

A counterargument might point to the evasion of some fundamental questions that art history now asks of these paintings, some of which must have been evident to Cowan. For example, despite all the cited death dates, Cowan plays down the fact that so many of the portraits were posthumous depictions, possible only because the subjects had lived in the era of photography. Whereas Mere Kuru eventually gave permission for her own portrait, her kinsman Taraia certainly did not, since Cowan's biography records that Taraia died in 1871that is, three years before Lindauer arrived in the colony. Even certain celebrities who were still living, such as the heroic rebel Rewi Manga Maniapoto, entered the gallery not through consenting participation but by virtue of having sat for a portrait at Pulman's Shortland Street studio in June 1879.

We also need to acknowledge that, apart from the odd evaluative comment such as that on Mere Kuru's portrait_-"one of his best"-and explanations of details such as Tukukino's flamboyant huia skin, Cowan pays very little attention to the paintings themselves. Instead, his emphasis is entirely on biographical data, and it is no surprise that contemporary reviewers should have hailed it as "a sort of Plutarch's Lives of Famous Maoris." ${ }^{25}$ Like Cowan, Plutarch was a bicultural scholar: a Greek who achieved fame for his biographies of famous Romans, paired with corresponding biographies of Greeks. ${ }^{26}$ And like Plutarch, Cowan was more interested in character traits and fascinating anecdotes than in history per se, 
for the point of each Life was to recount a sequence of dramatic events in a captivating style. Plutarch memorably likened his craft to that of a painter, drawing parallels between physical appearance and moral character, and I think this is how we must approach Cowan's contribution. What Pictures of Old New Zealand offers is a carefully crafted supplement to Lindauer's portraits, as opposed to the direct commentary and evaluation that would now be expected of a monograph on the work of a significant artist.

There is also an important difference between the ancient author and the modern. Whereas Plutarch was a colonised Greek, subject to Roman imperial authority, Cowan belonged to the colonising culture and made a leading contribution to popular and scholarly appropriations of the historical Māori past on behalf of a Pākehā posterity. Current Māori scholarship tends to approach work like Cowan's with suspicion, while acknowledging his rescue of historical voices such as that of Paratene Te Manu. ${ }^{27}$ For Pākehā scholars, it is the triumphalist depiction of cannibal savagery, safely contained in a long-ago place, that renders Cowan's work problematic. In my view, the book's value lies precisely in this uncomfortable, in-between status, as well as in its compelling narrative qualities. This is why Pictures of Old New Zealand needs to be republished in its original format, so that it can continue to servelike the Partridge Collection that it documents - as a portal to what, in 1930, was already a lost world.

\footnotetext{
${ }^{1}$ Pictures of Old New Zealand: The Partridge Collection of Maori Paintings by Gottfried Lindauer, described by James Cowan (Auckland: Whitcombe \& Tombs, 1930).

${ }^{2}$ Times Literary Supplement, quoted in "Lindauer's Pictures," Evening Post, 24 April 1931, 21.

${ }^{3}$ David Colquhoun, "Cowan, James, 1870-1943," Dictionary of New Zealand Biography, ed. Claudia Orange (Auckland and Wellington: Auckland University Press/Bridget Williams Books, 1996) vol. 3, $119-21$.

${ }^{4}$ Maori Biographies: Sketches of Old New Zealand, Compiled by James Cowan; Descriptive Catalogue of Maori Portraits painted by Herr G. Lindauer (Auckland: H. E. Partridge, 1901). ${ }^{5}$ Auckland Star, 30 August 1901, 4.

${ }^{6}$ For King Mahuta's inscription in the Visitors' Book, which follows immediately after that made by Patara Te Tuhi, see http://www.lindaueronline.co.nz/visitors-book/pages-015-016.

${ }^{7}$ A lengthy article by Cowan in September 1901 also addressed Tohunga under Tapu, a large painting illustrating the crucial Māori concept of tapu: "Maori Portrait Gallery: The Lindauer Collection," Auckland Star, 2 September 1901, 3.

8 "Lindauer Collection," New Zealand Herald, 1 April 1915, 8.

${ }^{9}$ In a letter to Partridge dated 25 November 1901, Mackay claimed personal acquaintance with 34 out of 40 subjects then represented in the collection (Pictures of Old New Zealand, 210-11). Mackay's texts are preserved in the Partridge Papers held at the E. H. McCormick Research Library at the Auckland Art Gallery Toi o Tāmaki. Transcriptions and digitised copies are accessible at Lindauer Online: http://www.lindaueronline.co.nz/artist/the-partridge-correspondence

${ }^{10}$ The comparisons made here are between the manuscripts and Pictures of Old New Zealand, as opposed to between Maori Biographies and Pictures of Old New Zealand.

${ }^{11}$ Pictures of Old New Zealand, 73. Dating from after 1901, the portrait is absent from Maori Biographies.

${ }^{12}$ Pictures of Old New Zealand, 74.

${ }^{13}$ Pictures of Old New Zealand, 59.

${ }^{14}$ Pictures of Old New Zealand, 56.

${ }^{15}$ Pictures of Old New Zealand, 59.

${ }^{16}$ Pictures of Old New Zealand, 145.
} 
${ }^{17}$ Some time in the mid-1980s, an irate Titewhai Harawira demanded to speak to whoever had written the label concerning her ancestor, Patuone. I attempted to explain that, though I was the hapless medium, responsibility for the offensive text lay with the long-absent James Cowan.

${ }^{18}$ An abridged version of Pictures of Old New Zealand, edited by Partridge's grandson, J. C. Graham, appeared as Maori Paintings: Pictures from the Partridge Collection of Paintings by Gottfried Lindauer (Wellington; Auckland: A. H. and A. W. Reed, 1965). Cowan's ghost also hovers over Briar Gordon and Peter Stupples, Gottfried Lindauer: His Life and Maori Art, (Auckland: Collins: Malcolm McGregor, 1985).

${ }^{19}$ Pictures of Old New Zealand, 52.

${ }^{20}$ J. E. Gorst, The Maori King; or, the Story of our Quarrel with the Natives of New Zealand (London: Macmillan, 1864); S. Percy Smith, History and Traditions of the Maoris of the West Coast, North Island of New Zealand prior to 1840 (New Plymouth: Polynesian Society, 1910); C. O. Davis, The Life and Times of Patuone, the Celebrated Ngapuhi Chief (Auckland: J. H. Field, 1876); F. E.

Maning, Old New Zealand; A Tale of the Good Old Times (Auckland: Robert J. Creighton and Alfred Scales, 1863); Thomas W. Gudgeon, Reminiscences of the War in New Zealand (London: Sampson Law, Marston, Searle and Rivington, 1879); Richard Taylor, Te Ika a Maui, or New Zealand and its Inhabitants (London: Wertheim and Macintosh, 1855; rev. ed. London and Wanganui 1870); Richard Taylor, The Past and Present of New Zealand; with its Prospects for the Future (London and Wanganui: William Macintosh/Henry Ireson Jones, 1868); Thomas Porter, Ropata Wahawaha, N.Z.C., M.L.C., the Story of his Life and Times (Gisborne: Poverty Bay Herald, 1897); William Lee Rees and Lily Rees, The Life and Times of Sir George Grey, K.C.B. (Auckland: Hutchinson, 1892); Alfred Domett, Ranolf and Amohia: A South-Sea Day-Dream (London: Smith, Elder and Co., 1872).

${ }^{21}$ Pictures of Old New Zealand, 150.

${ }^{22}$ Pictures of Old New Zealand, 78. Cowan's account of visiting the chief first appeared as "The Little Barrier: A Maori Eviction Pending," Auckland Star, 14 October 1895, 2.

${ }^{23}$ Eric Lee-Johnson, ed. Janet Paul (Hamilton: Paul's Book Arcade), 1956, 1-44.

${ }^{24}$ For a discussion of these visitors' books, see my "Te Pai o Ngā Āhua: The Visitors' Books at the Lindauer Art Gallery" in The Lives of Colonial Objects, ed. Annabel Cooper, Lachlan Paterson and Angela Wanhalla, (Dunedin: Otago University Press, forthcoming 2015), 210-15.

25 "A Maori Gallery: The Lindauer Collection, Pictures of Old New Zealand," Evening Post, 18 October 1930, 21.

${ }^{26}$ The Rise of Rome: Twelve Lives by Plutarch (London: Penguin Books, 2013).

${ }^{27}$ A particularly creative engagement with Cowan's text is the novel Rangatira (Auckland: Penguin Books, 2011), written by Paratene's descendant, Paula Morris. 